\title{
Ueno Park during Meiji Times - a Mirror of its Time: Discursive Space and Symbolic Representation of Modernity
}

\author{
Julia Rasche
}

\begin{abstract}
With the Great Council of State's 16th decree, the Meiji administration introduced the neologism kōen, 'public park', to the Japanese language and the administrative system. One of the re-named parks was today's Ueno Köen, which during the Meiji period changed with regards to character and appearance. It came to house the first modern museums, the first modern zoo, and the first public library. Industrial fairs were to be held in Ueno Köen and a train station was built, connecting the rural north with Japan's capital. Meiji politicians re-designed the park grounds, in which today not only institutions of education, industry and modernity are located, but the highest number of homeless people in any one place in Tökyō is to be found.

The research question, 'What kind of space was constituted in the place Ueno Köen during Meiji time?' is to be answered with the discourse theory of the German sociologist Reiner Keller and the theory on the social construction of space offered by the German sociologist Martina Löw. The article will show that Ueno Park was to become a spatial representation of Japan's modernisation process and of the policies of 'enlightenment' and 'rich country, strong army', bunmei kaika and fukoku kyōhei.
\end{abstract}

Keywords: Modernity, discourse theory, space, Meiji

Drae Rasche, Julia. "Ueno Park during Meiji Times - a Mirror of its Time: Discursive Space and Symbolic Representation of Modernity.” In Vienna Graduate Journal of East Asian Studies, Volume 1, eds. Rudiger Frank, Ingrid Getreuer-Kargl, Lukas Pokorny and Agnes Schick-Chen. Vienna: Praesens Verlag, 2011, pp. 91-122. https://doi.org/10.2478/vjeas-2011-0004 


\section{Introduction}

Ueno is for the eyes, a park with a view. Asakusa is for the mouth, a park for eating and drinking. Ueno puts a stop to things. From Asakusa you go on to other things. In Ueno even a Kagura dance is dour and gloomy; in Asakusa a prayer is cheerful. The vespers at Ueno urge you to go home; the matins at Asakusa urge you to come over. When you go to Ueno you feel that the day's work is not yet finished. When you go to Asakusa you feel that you have shaken off tomorrow's work. Ueno is silent, mute. Asakusa chatters on and on. (Saitō Ryoku'u, quoted in Seidensticker 1983: 119)

These words by the Japanese writer Saitō Ryoku'u 斉藤緑雨 (1868-1904) reflect a very specific view on Ueno Park (Ueno Köen 上野公園) - a park with a view that makes 'things' dour and gloomy, putting a stop to them while urging you to go home and keep on working. Why did Ueno appear silent and mute whereas Asakusa Kōen 浅草公園 (Asakusa Park), located in the shitamachi 下町, the low city, appeared as being full of life? While Saitō expressed himself so negatively towards Ueno Park, others could be equally passionate in condemning Asakusa Kōen, like the author of a newspaper article in the Köchiken Heimin 高知県平民 in 1874 . He stated that, when comparing Asakusa to the Western 'flower garden', whereas in the West the amusement of both sexes in the park was very pure, the amusement of the people in Asakusa Kōen was highly plebeian and rough and, in his opinion, hardly endurable (Maruyama 2003: 58). It seems that the institution of the public park could initiate highly opinionated discussions, and might even have served as a means to transport ideas that had nothing to do with the actual park. After all, a park is just a green area with benches, trees and paths, one would think. What kind of a space was Ueno Kōen during the Meiji era? Which spaces manifested themselves in the grounds of the park?

\section{Ueno Kōen, space and discourse}

Entering the park today, the visitor might get a peculiar impression of it. First, there is the large train station, in parts quite run-down, situated next to the Ame Yoko block アメ横, one of Tōkyōs most buzzing shopping streets, selling mostly cheap rummage. Depending on the entrance chosen, the atmosphere of the park the visitor perceives might vary greatly. From the south entrance, one passes the statue of Saigo Takamori 西郷隆盛, one of the most prominent figures of the Meiji Restoration, who became its opponent in 1873 and led the Satsuma Rebellion in 1877. Here, at least to me, the atmosphere presented itself as being very gloomy, enhanced by a man hiding in the bushes. It seems this impression was shared by others:

But it [Ueno Kōen] remains only a park in theory. In practice, it is a jumble of assorted buildings, all bearing little relationship, either spatial or architectural, to their neighbors, 
all interspersed with promenades and dirty clumps of vegetation behind which one half suspects some sort of lurking presence. On the other hand, in Ueno's defence, it should be said that, even if the parts fall short of making an acceptable whole, some of the parts themselves are, beyond dispute, more than acceptable. (Waley 1984: 159)

However, entering the park through the entrance closest to the train station, one ends up in close proximity to the National Museum for Western Art (Kokuritsu seiyo bijutsu hakubutsukan 国立西洋美術館). Proceeding further over the broad paths, one sees further museums like the Tōkyō Metropolitan Art Museum, a sports field, some temples and shrines. On Sundays, families visit the zoo or the little amusement park which is located in the park. Maybe the visitor will even notice the unusual number of older people, especially men, sitting on the park benches, enjoying the sun, wearing flip-flop shoes and resting beside their bicycles which might be stacked with incredibly huge mountains of drinking cans or old newspapers. The more perceptive visitor will certainly notice the kariya 仮屋, makeshift houses constructed mostly with blue plastic foil. Some of these tents seem to form small settlements, almost like little villages. At times, these tents are even decorated with flowerpots, and in front of them tame cats bathe in the sun. How odd, the visitor might think, that while tourists and other Japanese come to the park for its cultural institutions, just a few metres further on Christian welfare organisations offer free haircuts to the very poor.

Apart from Ueno being known as bunka no mori 文化の森, a place for high culture, it is also known as the one place in Japan's capital city with the highest density of homeless people (Iwata 2000: 45). Their little settlements are highly organised, as I learned when interviewing members of a small 'village' next to Shinobazu pond in Ueno Park. A leader assigns the tent spots, sets up rules of behaviour and has the power to exclude members for deviant behaviour. Surprisingly enough, most of these men in early old age and the two women who lived in that particular settlement, came from northern Japan.

It seems a place changes its character the more one knows about it, but also in accordance with one's own perception. The contrariness of today's Ueno Kōen led me to wonder about its history, but also about space and discourse.

The German sociologist Martina Löw defines space as a 'relationale (An)Ordnung sozialer Güter und Lebewesen (Menschen) an Orten', a relational ordering of objects and living beings (people) in places $^{1}$ (Löw 2001: 224). Common to all these 'bodies' is that they are 'products of present and especially past material and symbolic action' (Kreckel 1992: 77), in brief, social goods (Martina Löw 2003: 2).

1 Translations into English from German or Japanese have been made by the author if not stated otherwise. 
As the example with the kariya in today's Ueno Kōen shows, not only social goods but also people take part in the constitution of space - in their capacity as 'social goods' which are being positioned, in their capacity as agents who position themselves out of their free will, but also as space-perceiving, that is, spaceconstructing, entities. Both the people and the immovable social objects exert external effects, 'thus influencing the possibilities of spatial construction' (Löw 2003: 2).

A place is a concrete geographical point, and all space-constituting action, if it does not want to be purely metaphorical, generates real places, thus enabling space. The aim of all space-constituting action, seen as the placing of social goods, is the concrete place, which is also the result of the placing itself. However, after the space has dissolved, it is the place that remains, open for new positioning and further perceptions of space (Löw 2001: 224).

According to Löw, the placed objects are relational. Through the relations between the objects, as well as their symbolic content, space is generated, sometimes even transcending continents and national borders, as in the case of 'global cities' like London, Tōkyō, New York and so forth, which form their own space. Referring to Giddens's duality of structure, Löw constructs a duality of space - on the one hand it is people who place social goods, thus constituting space, on the other hand it is these spatial structures themselves that structure people and their practice. Consequentially, spatial structures, too, are always constraining and enabling (Löw 2001: 171, 178).

Through spacing, specific places are generated, but only through processes of perception can they be perceived as interrelated structures. Löw calls this synthesising perception synthesis, which includes processes of recall, perception and association. According to Löw, these are influenced by class, gender and habit.

My thesis is that discourse is a further factor that guides both individual and collective agents' synthesis of space. In the case of Ueno Kōen, a specific discourse was held during the Meiji era concerning ideas of the Western park. Ueno park and its objects, as well as the objects being interrelated to them, form a relational space in Martina Löw's sense, and can be connected to a specific discourse held in the 19th century. By analysing Ueno's objects - the museums, the zoo, the library and the industrial fairs, this discourse can be reconstructed. Using the theories of the sociologist Reiner Keller (Wissenssoziologische Diskursanalyse), I would like to view the objects placed in Ueno Park as a material representation of a specific discourse, thus constructing the park itself as a discursive space in which Meiji-time ideas and ideals as well as specific developments are mirrored.

Keller's aim is to strengthen the empiric ability of discursive theory. He emphasises the analysis of 'discursive processes of production, circulation, and manifestation of collective knowledge resources' (Keller 2005: 181). Discourse here not only refers to linguistic practice, but also societal practice and artefacts. In addition 
[...] as the discourse changes so do the objects of attention too. A discourse, moreover, is not merely a narrow set of linguistic practice, which reports on the world, but is composed of a whole assemblage of activities, events, objects, settings and epistemological precepts. (Prior 1989: 32, quoted by Keller 2005: 181)

Keller understands discourse as a mediating agent between a certain set of knowledge and social actors and, referring to Giddens's duality of structure, as both an enabling and constraining agent. Furthermore, discourses make rules available for the interpretation of the discursive meaning of certain phenomena. They guide practices of social actors who materially generate discursive events. However, not everybody fulfils the criteria for participation or has the resources at their disposal. In addition, the specific definition of reality that is guided by a discourse excludes other interpretations. Thus, the notion of discourse directly refers to power. Discursive structures, according to Keller, are simultaneously structures of power, and a struggle for control (Keller 2005: 203-204).

In order to analyse the discursive field of Ueno Kōen at the time it came to be Ueno Kōen, i.e. the Meiji era, I have taken a closer look at its space-constituting objects and the discourses that surrounded them at the time they were placed (spacing). The institutions erected in Ueno Kōen during the Meiji era were meant to distribute a specialised knowledge of the world to the public. The zoo, museums and the industrial fairs were institutions that introduced a specific form of sanctioned knowledge which was intended to influence people's way of thinking and acting in order to modernise and strengthen the nation state. As such, they can be viewed as a dispositif of the bunmei kaika 文明開化 and fukoku kyōhei 富国強兵 politics $^{2}$ and ideals of the time. Discursive events, like newspaper articles, which transformed and renewed the official discourse and described the institution of the public park as a symbol for societal equality, can be regarded as one of the discourse's unintended consequences as described by Giddens.

Keller allows for viewing Ueno Kōen as an objectivation of discourse, thus enabling us to explain certain ways of space-constituting synthesis and spacing. Why were certain objects placed in the grounds of Ueno Kōen? Which discourses are they related to (spacing)? Which discourses guided the perception of the public park (synthesis)? How did a powerful discourse that captured certain ideas of the construction of reality transform into spatial structures, thus again influencing the world construction of reflective, wilful social actors?

2 Bunmei kaika (enlightenment), fukoku kyōhei (enrichment of the nation through a strong military) 


\title{
Introduction of the public park to Japan
}

On 15 January 1873, the concept of the 'public park' was officially introduced to Japan through legislation in the 16th decree of the Dajōkan 太政官, the Great Council of State, which had been inaugurated in 1868. It was the first time the term kōen 公園, a term derived from the Chinese characters for kōoyyake 公 (public, official) and en 園 (garden) appeared in an official document (Suimatsu 1981: 30). The Japanese term yūen 遊園 (pleasure grounds, garden) had been replaced with a neologism, a direct translation from the Western public garden, indicating that 'Japan modelled itself after the European concept' (Shirahata 1992: 163). The significance of this neologism lies in the fact that it not only referred to the 'term of use', by which access to the park was open to the public irrelevant of class and gender, but also to the 'term of ownership', referring to property in the hands of the public, i.e. the public body.

With the 16th decree of the Dajōkan the legal groundwork for the institution of the public parks was created:

\begin{abstract}
Favourite spots of the populace, places that have been renowned for their scenic beauty since ancient times, places of historic interests, residencies of high-standing personalities as well as grounds which have been exempt from tax payments (for example the Kinryuzan Sensō-ji Temple and the Higashi Eizan Kan'ei-ji Temple in Tokyo and the Yasakasha Shrine, the Kiyomizu Temple, and Arashiyama in Kyoto), shall be places of recreation for the populace and shall hereafter be called kōen. The administration not only of the three $f u$ [府 - the municipal prefectures of Tōkyō, Ōsaka and Kyōtō], but also the ken [県], shall assign suitable grounds, attach detailed drawings and submit them to the Ministry of Finance for recognition. (Quoted in Suimatsu 1981: 30)
\end{abstract}

The decree was also published by the Tōkyō Nichinichi Shimbun 東京日々新聞 in 1873. The introduction even of old temple grounds into the new administrative system of the state not only implies 'modernisation', but implicitly Europeanisation: 'modern here is almost synonymous with "European"' (Shirahata 1992: 163).

Merely nine months later, the municipal prefecture of Tōkyō announced the existence of five public parks: Ueno, Asakayama 浅香山, Asakusa, Fukagawa 深川 and Shiba Kōen 芝公園, of which Ueno was the largest with 83.16 ha (Suimatsu 1981: 46). All of these grounds had been used as parks before they had been open to the public and did not change their outlook. What had changed? Quite simply, the administrative system. These grounds were now under a new administrative system, the public body giving guarantees for their existence and usage as well as for the conservation of the grounds. The legal ground of the parks had, by becoming public, changed. Shibusawa (1958) states a forced change of identity from 'public parks of the populace' to 'public parks of the administration'. The administration of the public parks was first subordinate to the Finance Ministry, and later became the respon- 
sibility of the Home Ministry after it came into being. This arrangement was stated clearly in the Kakushō kansei 各省完成 in 1886, which set out the administrative rules and responsibilities of all ministries (Suimatsu 1981: 17). The newly introduced system of local administration, of which the park was only one part, was stabilised and laid down in detail during the two decades which followed the Meiji Restoration. 'City and village are territorial authorities, under supervision of the responsible ministry they conduct the public administration within the confines of the law and according to law and tradition' (quoted in Suimatsu 1981: 17-18). With the coming into effect of the shichōson system 市町村, the communal order derived from the German model, more autonomous activity by the territorial authorities, which had been constructed as legal persons, was enabled. Only the three municipal prefectures were an exception, as their local self-administration had been restricted until 1898, when the special municipal law (shisei tokurei no haishi 市制特例の廃 止) was abandoned. During the 1880 s, park policies were regarded as part of hygiene policies, thus being situated in the Bureau for Health and Hygiene in 1897. No active park policy was pursued in that quarter, and a decline in the establishments of new parks up until the Kantō earthquake of 1923 can be observed. Only then, when parks became to be viewed as vital evacuation areas for the citizenry, did the state pursue the matter with more force again. But of course, and not only with regard to public parks, the new administrative system represented 'a thorough going break with the past' (Shibusawa 1958: 344).

What had preceded the announcement of the park declaration? What were the driving forces, which interests were pursued?

The implementation of the Japanese system of public parks mirrors, as explained above, part of the administrative restructuring of modern Japan, itself among the Japanese policies aiming at the abolition of the unequal treaties imposed on Japan by the Western powers. The park decree aimed at conserving old recreational grounds of the populace and finding a legal definition for temple and shrine grounds. In addition, it represented a striving to modernise, i.e. Europeanise, the cityscape of Japan with special emphasis on the capital city of Tōkyō. With regard to Tōkyō, a legal definition for the residencies of the daimyō 大名 had become necessary. Most of those had been abandoned with the end of the sankinkōtai system 参勤交替 in 1862, the system of alternating residency. Additionally, most of the Tokugawa entourage had left the city - Tōkyō lost half of its population as a consequence of the political changes at the end of the Tokugawa period and the beginning of the Meiji era, primarily in the more valuable residential areas of the city. The city was, at the same time, faced with an influx of poor people mainly from the agrarian north, who settled in the shitamachi, the low city (Seidensticker 1983:32; Zöllner 2006: 183). Still, Tōkyō had gained new open spaces, and with the park decree of 1873 there was a possibility of transforming some of them into public parks. 
The implementation of the park system stands in causal connection with the modernisation of the legal system, especially the land and tax reform, one of the most important reforms of the time. 'Legal reform was the groundwork for the regulation framework of the modern state' (Pascha 1994: 16), and the redefinition and guarantee of property rights were not only crucial to the entrepreneurs of the time, but also for a functioning modern state. Only through a definition of state properties, the establishment of an administration with the authority to issue directives and exert sovereign rights, was efficient state action possible. Land reform, moreover, opened new possibilities of income for the state. The central state replaced the various bakuhan 幕藩 imposts with a uniform system of land and other taxes, starting with a new survey of taxable land, which was then assigned a value and taxed, however, arbitrarily (Mason and Caiger 1997: 276).

In 1871, farmers were allowed to grow the crops they wanted on their lands, in 1872, the prohibition to sell land was abolished and the state began to hand out chiken 地券 (land titles). On 28 July 1873, it was announced that every land owner had to pay an annual tax of 3 percent of the land value, later reduced by Ōkubo Toshimichi 大久保利通 to 2.5 percent following social uprisings (Zöllner 2006: 215). Thus, the central government had a solid financial income, and until 1910, land tax was the single biggest form of financial income of the state - in 1875 it covered 85 percent of national income and in 1905 was still 32 percent (Zöllner 2006: 216).

Inōe Kaoru 井上馨, at the time finance minister, anticipated difficulties with the introduction of the tax reform with regards to temple and shrine grounds that needed to be taxed: 'If formerly tax-exempt grounds were taxed, there will be an imminent risk of their subsequent commercial use to raise the necessary tax money. Subsequently the population would lose their recreational areas' (Kokuritsu kōbun shokan: Dajō ruiten, quoted in Shirahata 1995: 180). The other Sei-In 正院 members, Sanjō Sanetomi, Saigō Takamori, Hagaki Taisui and Ōkuma Kotomichi - Kido and Iwakura were still travelling in the West - seem to have agreed. Only two weeks later, the park decree was proclaimed.

When modern city development was institutionalised in 1884, Western cities like Berlin, Paris, Vienna and London served as role models. In 1885, a member of the city development committee voiced his ideas about city parks, stating that Asakusa and Shiba Kōen should become like Park Monceau in Paris and become the gardens for the common people, whereas Ueno, similar to the Bois de Boulogne, should serve the nobility (Shirahata 1995: 187).

To achieve the desired number of parks relative to the size of park grounds for Tōkyō, a set ratio of the number of inhabitants to surface area was taken. In spite of this rather formal approach, park area decreased until 1942, despite efforts to open new parks as evacuation areas after the devastating Kanto earthquake in 1923 (Suimatsu 1981: 12). 


\section{A 'real' park - symbolic representation of ideas?}

With the Meiji era, new political ideas and concepts came to Japan. The idea of the 'public' was one of them. The notion of the 'public' was not only introduced through the public park. The introduction of new political ideas and legal norms made the term necessary in a number of newly introduced expressions, thus giving rise to the problem of semantic transparency. Terms like public pronouncement, public official, public election are but a few examples of the new words introduced to the Japanese language (Maruyama 2003: 78). The introduction of new expressions and concepts without introduction of the evolution and context of those ideas often changed and transformed the transported contents of the context (Howland 2002: 30). The concept of the 'public' was discussed in the flourishing newspapers. In November 1874, an article published in the Choya Shimbun 朝野新聞 discussed whether composites with the Chinese character for public ( $k \bar{o} / \bar{o} y a k e$ 公) should not be exchanged for their corresponding foreign word. In the author's view, this specific character carried a strong cultural notion of authority. With this authoritarian connotation, instead of emphasising the empowerment of the people that the expression 'public' implied in the West, according to the writer's opinion, the Chinese character concealed the concept of the public, the common. By use of the loan word 'public', the authoritarian, Confucian connotation would be avoided. This way it would be clear that the expression 'public' referred to the fact that things were owned by every one of the people, making even the emperor one amongst others, because "if one said "public" all would become equal (public no mono to ieheba mina dōyo nari, パブイック物トイヘバ皆同様ナリ。。。)' (Chōya Shimbun 13 November 1874, quoted in Maruyama 2003: 57)

Still, in spite of the above mentioned doubts, at the end of the Meiji period the transformation from official to public was coming into being and the self-conception of the subject was changing, by comparison with the Japanese of early Meiji times

[...] their grandchildren were displaying the characteristics of modern citizens: writing letters to newspaper editors to discuss matters in the legislature, marching in the streets by the tens of thousands to demand lower streetcar fares and an aggressive foreign policy, using phrases such as 'constitutionalism' and 'the peoples will' as if they were second nature. (Huffman 1997: 2)

This was all the more astonishing in view of the Imperial Prescript on Education, which had been issued in 1890: 'Know ye, Our subjects', it began, 'using the newly coined compound term shinmin to denote "loyal-officials-directly-subordinated-tothe-emperor, and people-who-obediently-comply-with-their-orders." Then it went on to list the Confucian virtues (Bix 2000: 30). 
In addition, the public space of the parks had changed, when on the occasion of the Hibiya Yakuichi Jiken 日比谷焼打事件 ${ }^{3}$ in 1905 the people demonstrated in Hibiya Kōen 日比谷公園. At the end of the Meiji era, the notion of the public had arrived in society - the public park being an embodiment of the concept. Only this can explain the indignation of a journalist of the Ōsaka Heimin Shimbun 大阪平民 新 on the occasion of the planned erection of a private house on the grounds of a park in 1907: 'Why and for whom has the park been constructed? Of course for the citizens, the lower classes of society, the poor, people like me, not for the rich and posh!' (Maruyama 2003: 79)

What was a real park, and how did the ideas expressed through the symbol of the public gardens change over the decades, from its implementation in 1873 to the end of the Meiji era in 1912? The following dialogue, also published in the $\bar{O}_{s a k a}$ Heimin Shimbun in 1907, is one example of how people used the public park to express their political ideas, in this instance presenting the park as a concrete example of socialism:

\begin{abstract}
'Whenever one looks, the Ueno Park is always beautiful, isn't it?' - 'Yes - it is so comfortable to sit on the benches that don't cost anything!' - 'Yeah, the benches are alright, but what I really want is my house to be here.' - 'Is that possible?' -'Well, once I have spoken to the right people, it most certainly is!' - 'Maybe for people like you, definitely not for me...' - 'Just wait and see, I will talk them into it, and you will get your own house in the park, too.' - 'But what will others think of it?' - 'I don't care about others!' 'If you want a house in the park, others will want the same.' - 'Well, if they want it - anybody can take it' - 'There will be fighting...If you erect your house here, loads of people will lose their recreational grounds. You only think of yourself!' - 'Yes, you are right...for the others, it would be a shame.' - 'For this reason it is better to leave the park as it is common property of everybody. This way, everybody can use the grounds. What is more, look at the mansion there... [...] Wouldn't it be better to take away the fence and make it part of the park?' - 'Ah, now I understand! You mean we should not turn public parks into mansions, but mansions into public parks? That is socialism, isn't it? If that is so, I can agree!' (Ōsaka Heimin Shimbun 15 October 1907, quoted in Maruyama 2003: 76-77)
\end{abstract}

Although Tōkyō had lost half of its former inhabitants in the 1860s, with rural outmigration it also gained new - mostly poor - inhabitants. In the beginning of the Meiji era, approximately 1.3 million people lived in Tōkyō, which resulted in a population density of 235 persons per hectare, but in the less affluent areas of the city, the ratio jumped up to 673 persons per hectare (Suimatsu 1981: 27-28). Albeit population numbers during Meiji times cannot be entirely trusted, and in 1878 overall numbers had dropped to 670,000, one can safely assume that living conditions of the poor were bad (Shibusawa 1958: 333). They were probably the ones most in

3 On the occasion of the peace Treaty of Portsmouth, which ended the Russo-Japanese war, citizens of Tōkyō voiced their disappointment about the treaty loudly during a demonstration in Hibiya Kōen (5 September 1905), which led to riots all over Tōkyō, mostly led by the urban under classes. 
need of public open spaces, in this way making the public park an obvious choice for political discussions. This might also help to explain the hopes that Yoshida Kōzō, chairman of the construction committee of Hibiya Kōen, linked to the newly designed and constructed park.

In 1904, when the construction work for Hibiya Kōen was begun, he pointed out that

[...] we have more than 232 parks in the city of the emperor, but in spite of this, the parks opened on former shrine and temple grounds are not real parks. They are not made to shake off the worries of the day and lift the spirits. However, Hibiya Kōen will really meet the demands. (Tōkyō no kōen. Sono 90 nen no ayumi, quoted in Shirahata 1995: 167)

Hibiya was one of the first parks which had a completely different history to the parks of the park decree. It was designed as a public park after a German draft and especially built to meet certain (modern) demands. This might explain why, whereas Kōzō praises Hibiya as the perfect park - implicitly only for the upper classes others criticise its proximity to the Hotel Imperial and government offices (Maruyama 2003: 71-72). Hibiya became a park of the upper classes through its symbolic barriers of entry - the German design, the surroundings, and the class of people which was present. Quite obviously the atmosphere created, the placed social goods and people and the discursive surroundings succeeded in creating a social space that implicitly excluded certain groups of people from active participation in the social life taking place in Hibiya Kōen. But only a year later, the public expressed its opinion during the Yakuichi Jiken exactly there, in Hibiya Kōen.

\section{The public park as an area of 'edu-tainment'}

Japanese delegations had already been sent to the West during the bakumatsu 幕末, the final years of the Edo period. They came home with new ideas, new technologies and vivid descriptions of Western cities. At the end of the Edo period, Western parks had been described as paradises (Shirahata 1995: 171). Although the travellers hardly ever failed to mention the park's double function as recreational space and space for the deployment of the military in case of emergency, thereby discursively producing the necessity of parks through their practical usage, the emphasis was mostly put on the social advantages: recreation, an air filter for polluted cities, and an overall symbol of enlightenment and education (Maruyama 2003: 61). Already in 1860, a delegation of 77 Japanese travelled to the West. In their reports, they also mentioned the public parks. 'On all corners of the city parks have been built. Around a square of sometimes just $200 \mathrm{~m}$ in its side length, an iron fence has been put up. In its interior plants and trees have been planted, and fountains which produce a highly elegant atmosphere are to be found. On public holidays and Sundays, when the 
shops are closed, the citizens proceed to the park after church [...]' (Nagata Tomisaku 1946:90; quoted in Maruyama 2003:53). A detailed description of Central Park follows. Sano Kanae 佐野鼎 calls it a park not to be found a second time in North America in his diary. According to him, all inhabitants of the city, both poor and rich, took walks in the park (Maruyama 2003: 54). Hosogawa Junjirō 細川潤次郎, another commentator from the San Francisco industrial fair in 1871, wrote with astonishment that although people from the low classes were present in the park, everything was very quiet. Even on Sundays, when both old and young people, men and women were in the parks to read the paper, eat and drink, no drunkards were present, and the visit to the park remained an elegant pleasure (Maruyama 2003: 55). It seems only a few, like Kurimoto Joun 栗本鋤雲, who travelled with the Iwakura mission, noticed that European parks were constructed and build for different groups of society (Shirahata 1995: 171).

People like the intellectual Fukuzawa Yukichi 副沢 and Machida Hisanari 町田 久成, later the founding director of the Tōkyō National Museum, introduced the idea of the park as an arrangement of museums, public libraries and zoological gardens inside a park area (Shirahata 1995: 170). This broad perception of the park space became a symbol of enlightenment, and was to influence the composition of Ueno Kōen later on. Even though

[...] the notion of what a park should be was a confused one. The Edo equivalent had been the grounds of temple and shrine. The park system of 1873 tended to perpetuate this concept, merely furnishing certain tracts a new and enlightened name. Ueno was almost empty at the outset and presently became royal, and ended up rather similar to the city parks of the West. (Seidensticker 1983: 119-120)

The result of Ueno Kōen ending up rather similar to the city parks of the West, as Seidensticker writes, was intentional. Its elements had been designed to be European, to carry a certain idea of parks.

The early Japanese travellers had been astonished by European and American cities and their public institutions - the museums, railway stations and, last but not least, the public parks. Although Japan had its own gardens, and was in many areas of horticulture much more advanced than the West, the park as a symbol of enlightenment was new. When the Japanese travelled to Europe, Europeans were rebuilding their cities from medieval towns into imperial cities. Broad boulevards were constructed in lieu of the old city walls, rendered unnecessary by new military technology, and the bourgeoisie opened public parks to show off their new selfconscientiousness and lifestyle (even though, in cities like Berlin and Vienna most parks had been opened by the authorities, and their usage was restricted by class. For example, park benches had to be left for the nobility when the latter claimed them). However, in other cities in the German-speaking world, parks were opened up through the initiative of the new middle class, giving space to, and representing, 
their very specific tastes and lifestyles (Shirahata 1995: 19-21). Thus, the European park became an ideal, according to Shirahata. 'It is [...] the combination of some European techniques and the European concept to combine them that produced a park' (Shirahata 1992: 175). From 1860 onwards, when the first delegations were sent to the West, the Western public park presented itself to the Japanese travellers as a shared characteristic of all Western cities, symbol of a modern, progressive and enlightened society, while the cultural differences of the different parks as well as their symbolism were, at least according to Shirahata, mostly not recognised (Shirahata 1995: 5).

Still, the question remains - what was a 'real' park? Why were the five parks which became kōen in 1873 not recognised as real parks by many, for example? Several aspects seem to matter in the definition of a park: a green open space that is open to the public; a public space according to legal regulation; a consciously designed space. A real park is, drawing from Martina Löw's theory, the result of relational spacing in a marked-off area. The protagonists' perception is dependent on the arrangement of placed objects and people. The usage of the park had been defined as both recreational and educational, thus serving the reproduction of cultural and social capital. As definition and usage are dependent on the cultural background of the protagonists, it becomes apparent that it is a cultural product. Being a play of technique and culture, the park becomes a symbol of the culture which is materialised in it. From the view of the Meiji-era protagonists, there was the Japanese park as a cultural artefact (bunka sōchi 文化装置), and the Western park as a symbol for enlightenment (bunmei sōchi 文明装置).

\section{Ueno Kōen prior to 1873}

Compared to the other four parks in Tōkyō, which were transformed into kōen in 1873, Ueno has a remarkably different history, which has always been intricately connected to the sphere of state power and the representation of power. In 1624, the Buddhist Kan'eiji temple was built on Ueno no Yama, initiating rapid urban settlement in the area, and moreover constituting the 'devil's gate' to the, according to Chinese geomancy, ill-omened north-eastern direction (Waley 1984: 153). Further adding to the symbolic content of the area was the fact that the Tokugawa chose the temple complex situated to its south as their family temple. The area had thus been assigned a representative function, additional to the recreational and religious one possibly one of the reasons why it became so difficult for Meiji-period protagonists to assign a new function to it after 1868 when the Ministry of Education, the Home Ministry and the military put forth their claims to the area (Taitō-ku shi shisan senmon iinkai 2001: 43). In 1868, the area of the present-day Ueno Kōen became the stage for the so called Ueno-Sensō, the Ueno War, when 2000 fighters of the shōgi- 
tai 彰義隊 ${ }^{4}$ fought the imperial troops (Seidensticker 1983: 27; Suimatsu 1981: 45). Although this was the last time actual fighting took place in the district, in 1877 troops were again stationed in Ueno during the Seinan-sensō 西南戦争, the Satsuma Rebellion, against the adversaries of Meiji politics.

It seems that both the history of the place as well as its geographical suitability for different institutions of the modern state, made it exceedingly difficult to assign a function to the grounds of Ueno Park. However, the Dutch embassy claimed that although modern institutions like hospitals might be crucial for the nation state, parks and squares fulfilled important functions in modern cities. Therefore Tōkyō too needed such places. Only then was the decision made to turn Ueno into a park (Taitō-ku shi shisan senmon iinkai 2001: 44).

Concerning its administrative structure, Ueno is an exception from the general administration of public parks in modern Japan. From October 1873 to 1879, it was mainly administered by the municipal prefecture of Tōkyō, until it became subordinate to the Home Ministry in 1881; until 1886 it was under the guidance of the Nōshōmushō 農商務省, the ministry of agriculture and commerce, only to be transferred to the Imperial Household Ministry in 1886. There it remained until 1924, when Ueno Kōen was given to the city of Tōkyō in commemoration of Crown Prince Hirohito's wedding (Suimatsu 1981: 91). This exceptional position amongst the five parks allows for the definition of Ueno Kōen as a symbolic space in which during the Meiji period, different discursive claims of power and political developments became materially manifest.

\section{Ueno station and the race track at Shinobazu pond: symbols of $f u$ - koku kyōhei politics}

In the following section, the main spatial objects, understood as mediating instances between discourse and reality, will be presented. As it was these spatial objects that made up the space of Ueno Kōen and influenced the synthesis of the space, I would like to draw attention to their surrounding discourses. As spatial objects it was especially the train station, the horse race track, the museums and industrial fairs that in my opinion shaped the park during the 19th century.

Ueno station, located at the edge of Ueno Kōen, was opened in 1883, the first train station connecting the imperial city of Tōkyō with the rural north. One of the first train stations in the country, it must have been impressive with its Western design and the huge steam trains, noisy and smelly.

4 Around 3,000 samurai who called themselves 'troops of clear duty' (shögitai), Tokugawa followers who fought the Meiji troops (Zöllner 2006: 183). 
When Japan developed the high-speed train Shinkansen in 1964, it set itself at the top of international railway development. Up to that date, however, it had been a conflict-ridden path, but in the international context very short. Conflicts arose along the lines of private versus state involvement, property rights, national against international influence as well as the general problem of the allocation of national resources. Fifteen years after Commodore Perry had brought the model of a steam train to Japan, in 1869 the Dajōkan decided to build the first railway lines in the country (Bersihand 1963: 333). Soon, Japanese politicians, just as Western ones, came to view the development of a communication and transport network as a vital part of 'nation-building'. However, in the beginning of the Meiji era, the idea of a Japanese railway system met with a lot of opposition, from politicians, who feared the overwhelming, but in the circumstances necessary, influence of Western engineers, financiers and planners, from the farmers who did not want to give up their farmland for railway tracks, and especially from the military, which wanted the huge sums of money necessary for infrastructural development to be spent on military equipment instead. Additionally, xenophobic sentiments, especially amongst the military, played a role in delaying railroad construction.

Saigō Takamori, who had become supreme commander of the armed forces in 1870, especially opposed the idea of the establishment of a national railway system in Japan. He wanted the sparse resources of the state to be spent directly on the military sector. Ironically, it was his influence that convinced the army later on of the necessity of a well- developed infrastructure to enforce the power of the central state. In 1877, when Saigō led the Seinan-sensō, the Satsuma Revolt, the railway system proved its usefulness, when troops could be transported quickly and efficiently between Tōkyō and Yokohama (26,000 soldiers) as well as between Kobe and Kyōto (3,200 military personnel) (Ericson 1996: 121, 411). After that event, an infrastructure that covered the entire country seemed desirable, and a link between Tōkyō and northern Honshū was part of the political agenda (Taitō-ku shisan senmon iinkai 2001: 35).

In 1870, Ōkuma advised Maejima Hisoka 前島密, at that time employee of the Finance Ministry, to devise a statement of cost for the railway sector. Maejima proposed establishing joint stock companies with an interest rate of 12 percent for private capital. Administration and operation of the railway lines should, according to his idea, remain under the control of the state. The Finance Ministry, being aware of the costs for a public railway system, was from the beginning in favour of private initiative, whereas the Ministry of Public Works under Yamao Yōzō 山尾庸三 opposed that idea vehemently. According to the Yamao formula, all railway ventures were to be publicly financed and administered (Ericson 1996: 103). Nonetheless, five years later the Dajōkan, in view of the financial situation of the state, accepted the sale of the Tōkyō-Yokohama line to the private Tōkyō Railway Association, 
which had been founded with the help of Iwakura Tomomi 岩倉具視, Minister of the Right. Iwakura was one of the most influential politicians to drive forward the idea of a railway connection from Tōkyō to Aomori: 'A nationwide railway system will constitute an inestimable asset for the prosperity of our people. It is, moreover, a critical endeavour that we have to venture upon out of a deep-rooted feeling of loyalty towards the emperor' (Iwakura Kojiki, quoted in Taitō-ku shisan senmon iinkai 2001: 36). Iwakura forced the sale of the Tōkyō-Shimbashi-Yokohama line, because he viewed it as an excellent opportunity to open up new financial possibilities to the state on the one hand, but also to offer the old samurai elite a new field of activity that would not only integrate them into the new political system, but also provide them with a new possibility of earning their livelihood by participating in the country's new prosperity. After the state had introduced general conscription, the old elite had lost their raison d'être, while the state's finances were strained by the stipends paid to the old military class, which constituted up to 30 percent of state expenditure (Zöllner 2005: 211). Financial cooperation between the former samurai and daimyō and the state not only meant a relief for the state, but a way to recycle the alimony the state was handing out to the former ruling class (Ericson 1996: 105).

In October 1881, the Nihon Tetsudō Kaisha 日本鉄道会社 (NTK), successor of the former Tōkyō Railway Association, was awarded the licence to build a railway line from Tōkyō to Maebashi in Aomori (Mason and Caiger 1997: 273). In spite of extensive state control in this joint venture, the NTK's activity was a kick-off for private enterprise in the railway sector (Ericson 1996: 116; Taitō-ku shisan senmon iinkai 2001: 40). Its first business report in 1884 initiated a boom in private railway enterprise, and already in 1889 the private railway lines were longer than the state lines (Mason and Caiger 1997: 273). The deflationary policies of Matsukata Masayoshi 松方正義 during his time as finance minister further pushed private investments (Hall 1994: 298).

Iwakura Tomomi helped to promote the railway boom by interesting the broad public in the railway system, thus raising additional funds. These had become necessary since the original idea of the NTK and the state to build a nationwide railway system proved to be unrealistic because of insufficient funds. Iwakura set up a press conference and addressed the media. He emphasised the necessity of a nationwide railway system for Japan, explaining the prosperity of the Western countries through their infrastructure, which made possible the transportation of goods and soldiers by land as well as by sea. He considered it was therefore vital for Japan to use steam ships and locomotives. Moreover, he asked the journalists and publisher present to 'bend their brushes and let the sentences dance on the newspaper' when discussing that important issue which to his mind was so crucial to the economic and military development of the nation state (Taitō-ku shisan senmon iinkai 2001: 37). Quite clearly, the railway as a vehicle to launch economic and military progress had be- 
come a proponent of the fukoku kyōhei 富国強兵 politics. The railway influentially changed Japanese society - for example, in the perception of time and space, which found its expression in the exchange of the traditional qualitative time system handoki 半時 for the monochrone quantitative Western minute. Also, social structure gradually changed with the opportunity to separate one's work place from the place where one lived, home. But mostly the railway changed the economic landscape of Japan since for many communities in the countryside, the connection to the railway system could spur economic success - or without it, economic stagnation or even economic demise (Ericson 1996: 62-72).

When Ueno station was opened in 1883, it took another eight years before a traveller could board the train in Maebashi and step of in Tōkyō, maybe visiting the capital for the first time. By now, the local elites along the railway line were mostly enthusiastic about the connection to the capital, and even contributed by gifting land for railway construction. During the 1880s, the railway had become a symbol for civilisation. Already in the 1870 s it had been a very popular motive, depicted on iroha card games いろはカルタ and wood block prints, a visible, audible and olfactory symbol of the new times. Even those who superstitiously feared the black iron steam monster were becoming fewer and fewer. The inhabitants of the prefecture Nagano, who opposed railway construction in the middle of the 1880 s because they were afraid the train signal might shorten their lives, were amongst the last with a superstitious fear of the train (Ericson 1996: 59-63).

Ueno station came to connect the agrarian north to the centre of culture and economics as well as to the rest of the country. It was the place where many travellers from the north entered their capital for the first time in their lives, the point of entry for the many seasonal workers, who left the agrarian north to find sources of income in the big city. This not only led to increased passenger traffic, but also to technology and cultural transfer (Waley 1984: 151).

One year after Ueno station was opened amidst festivity, a horse race track along the shores of Shinobazu pond was inaugurated for the public (Taitō-ku shisan senmon iinkai 2001: 66). The emperor turned up for the opening ceremonies, emphasising its importance with his visit. The race track supported itself through entry fees and donations, not through betting, because 'the purpose, most Meiji-like, was not pleasure or gambling, but the promotion of horsemanship in the interest of national defense' (Seidensticker 1983: 118). Just like the train system, which owed its quick advance to its advantages in the military sector, the horse race track was one more representation of fukoku kyōhei politics and symbolic military power on the grounds of Ueno Park. 


\section{Bunmei Kaika: museums in Ueno Kōen, dispositif of knowledge}

The implementation of a museum as a container of historical artefacts on the one hand and of witnesses of technological progress on the other hand clearly is a dispositif of knowledge - and power. The museums were meant to act as a mediating instance between politically sanctioned or even desired knowledge and their visitors. Two of the first permanent museums in Japan were built on the grounds of Ueno Kōen. One was the present-day Kokuritsu Kagaku Hakubutsukan 国立科学博物館 (National Science Museum), which was opened in 1877 in Ueno as Kyōiku hakubutsukan (Educational Museum), administered by the Ministry of Education. The other was the predecessor of today’s Tōkyō Kokuritsu Hakubutusukan 国立博物館 (National Museum), opened under a simple name under the administration of the Home Ministry in Meiji 15, that is, 1882. With the word hakubutsukan 博物館 (museum) another neologism had found its way into everyday Japanese language. This museum incorporated the former Askakusa Library, predecessor of today's National Library (Seki 2005: V).

Three men had considerable influence in the construction of the museums: Sano Tsunetami 佐野常民 (1822-1902), who served as minister of agriculture and commerce and later became a member of the Privy Council, the Home Minister Ōkubo Toshimichi (1830-78) and the later museum director Machida Hisanari (1838-1897).

When Sano returned from the World Exhibition in Vienna 1873, he already wanted to open a museum in Japan, as he was convinced that, much more than any hearsay and book reading, a technical museum with exhibitions that could be directly experienced would serve the educational progress of the Japanese people. According to his opinion, such a museum should be located in a park, alongside botanical and zoological gardens, to not only educate, but to enlighten the people (Maruyama 2003: 62). His idea was to build a museum where visitors were allowed to even touch and try out new technology. He proposed Ueno Kōen as the most suitable area for such an endeavour (Taitō-ku shisan senmon iinkai 2001: 47-48).

Machida Hisanari on the other hand, who had travelled to the Paris World Exhibition, had campaigned for a historical museum ever since the Meiji restoration. The necessity for such an institution became apparent after Shintō and Buddhism were separated by law in 1868 in preparation for state Shintō. Civil servants and priests understood the government's intent as an attack on Buddhism, and an anti-Buddhist iconoclasm (haibutsu kishaku 廃仏毀釈) took place (Lokowandt 1976: 31). With the additional sell-off of cultural artefacts to foreigners, intellectuals angrily voiced their criticism of the official ignorance of the country's Buddhist history and its cultural artefacts (Seki 2005: 76). In 1871, the heyday of the iconoclasm, the Dajōkan issued a law for the protection of cultural artefacts, simultaneously initiating a survey of the country's objects of cultural value, of which Machida was in charge. Such an inventory had last been conducted in 1800, when Matsudaira Sadanobu 松 
平定信 published his Shūko jisshu 集古十種, Ten Categories of Collected Antiquities, but in the second half of the century, not even the temples possessed complete inventory lists (Seki 2005: 77-81, 31). In 1876, the Dajōkan issued decrees number 55 and number 56, making it a crime to hide cultural artefacts, while at the same time inscribing that every piece turned in to the authorities would be compensated for in cash. Both the land owner, on whose land the valuable artefact was found, as well as the finder were entitled to remuneration. Cultural artefacts was defined as cultural treasures which bear testimony to the change of times, of form of government, of customs and traditions (Seki 20005: 77-78). These laws resulted, in addition to further reclamation of land, to ever more artefacts being turned in. They were later to become part of museum exhibitions (Seki 2005: 103-105).

Sano anticipated a technical museum, very much like the Smithsonian in Washington, which had opened its gates only in 1846. However, the benefit of costly museums, which very often served also as research and education centres, was not clear to his contemporaries. According to the historian Seki Hideo, without Ōkubo's patronage, they would never have been realised (Seki 2005: 34-35). In 1875, Ōkubo had already asked the Dajōkan to build a museum, explaining that the Kensington Museum had, as an educational institution, helped to promote the international success of the British economy. To Ōkubo, the foundations of a strong nation state were industry and trade, and to him, along with the shokusan kōgyo initiative 殖産興 that from 1870 onwards aimed at promoting Japanese industry, the idea of a museum was part of fukoku kyōhei politics (Seki 2005: 125-29).

Both Machida and Sano dreamed of a 'scientific park', in which industrial technology, natural science, innovations and history found their representation, and all three proponents suggested Ueno Kōen. Machida devised a concept for a 'museum park', comprising museums, a zoo and a public library. His concept was realised on the grounds of Ueno Kōen, transforming the park from a recreational and religious area into an instrument of enlightenment and modernisation (Maruyama 2003: 6263).

The Kyōiku Hakubutsukan became an integral part of the educational system, supplying schools with books and samples. Firstly, it was planned as a scientific and much specialised museum, but later on the idea of a science museum came up when Tanaka Fujimaru, state secretary in the Education Ministry, learned about the educational museum in Canada. The concept was changed, and from then on the museum was meant to support the school system. Research resources were to be centralised and made open to the public. Starting in 1884, public natural scientific experiments were conducted once a year. Entry both to the museum and the experiments was free of charge, and visitor numbers rose from 176,748 visitors when the museum opened its gates on 18 August 1877, to 207,658 visitors in 1881 (Taitō-ku shisan senmon iinkai 2001: 54). 
1,400 guests were present during the opening ceremony of the Home Ministry's Hakubutsuan in 1882, amongst others state ministers, foreign ambassadors, secretaries of state and the chairman of the Sūmitsuin 枢密院, the Privy Council. But again, it was the Meiji emperor's presence, emphasising the event's importance to the state, that made the event grand (Seki 2005: 154-155). In 1888, with the relocation of Asakusa Bunko 浅草文庫 (Asakusa Library), a library was incorporated into the museum, and along with the zoo which also opened its gates in 1882, an idealised Western park as an entity of educational institutions and arranged plants had been realised. The zoo extended the idea of the hanatori chaya 花鳥茶屋 of earlier times, exhibitions of animals, which had been mere spectacles. Now Japan had introduced the idea of a modern zoo under scientific guidance, which conducted science and education, but also offered relaxation for its visitors. A further institution that made Ueno Kōen, it resembles the Jardin des Plantes in Paris (Taitō-ku shisan senmon iinkai 2001: 59).

The zoo soon became an expression of the state's foreign relations: in 1888, it received an elephant as a gift from the Siam monarchy, and 1895 the Chinese loots of war increased the annual visitor numbers to 300,000 . However, the absolute attraction was a lion from Hagenbeck's animal collection in Hamburg, the later Hagenbecks Tierpark - it nearly doubled the visitor numbers to 947,000 in 1902 (Taitō-ku shisan senmon iinkai 2001: 62). The zoo as a completion of the idealised space of the park thrilled the visitors, showing them an unknown world most of them would never travel through, constituting a heterotopic space of illusion and compensation.

\section{Hakurankai : fukoku kyōhei and bunmei kaika}

Four industrial exhibitions were held on the grounds of Ueno Kōen during the Meiji era: in 1877, 1881, 1890 and 1907. These hakurankai 博覧会 completed the Ueno Kōen space as a symbolic space of education, enlightenment and the advancement of modernity. Again, Ōkubo Toshimichi and Sano Tsunetami were the driving forces behind these events.

The first information the Japanese acquired about Western-type industrial exhibitions was through articles printed in the Batavia Shimbun バタビア新 announcing the international exhibition in London 1862. The newspaper was published by the Dutch occupation government in Indonesia, and was translated by the bakufu 幕府 (Hashizume 2005: 4). The European industrial exhibitions were linked to the industrial revolution and the beginning of industrial capitalism with its new forms of production and manufacturing in Europe. Beginning with the industrial fair in England in 1756, followed by a French one in 1798 which was initiated by Napoleon, they soon became a stage on which nations competed with each other to show off their 
achievements in the industrial sector (Dirlmeier et al. 1999: 244). Grand world exhibitions were to follow in the 19th century, 1851 and 1863 in London, 1867 in Paris, 1873 in Vienna, playing the role of a 'motor' which introduced and enabled innovations (Hashizume 2005: 4). In Paris, the Tokugawa bakufu and the Satsuma and Saga han had participated, and with the Viennese exhibition of 1873 the Meiji government sent its own delegation to Vienna. Being painfully aware that Japanese industry had not much to offer in an international context in terms of international standards, the exhibited show pieces of Japanese cultural technique were not representative, especially since the Japanese strived to give the picture of a 'civilised' nation. Even ukiyo-e prints 浮世絵 - woodblock prints - were considered vulgar and were, therefore, deemed unfit for the international competition between nations (Zöllner 2006: 223).

In a speech the Austrian emperor Franz Josef I gave on the occasion of the Vienna exhibition, he stressed that the fair stimulated innovative talent, constituted a peaceful competition between nations, served diplomatic exchange and enhanced a nation's reputation (Karl Richter 1877: 29, quoted in Exposeeum 2000). This view of international exhibitions might help to explain why Japan, having won its first war against a European power, started planning an international exhibition in Japan for 1912. Economic recession forced it to be postponed to 1940, the year of the alleged 2600th birthday of the Japanese monarchy. But again, the fair had to be postponed, in the end taking place in Ōsaka in 1970 as the first world exhibition on the Asian continent (Hashizume 2005: 7).

The first exhibition in Japan for which the newly devised compound word hakurankai was used took place in Kyōto in 1871. Less an industrial fair than a temporary museum, it started a real hakurankai boom in Japan (Hashizume 2005: 6). These exhibitions were probably the first to address a broad public with an educational agenda, but they were by no means the first exhibitions ever to be held in Japan. Already in 1762, the botanist Hiraga Gennai had initiated the exhibition of different herbal remedies during so-called bussan-e 物産会 and honzo- $e$ 本草会, exhibitions of medical crops and herbs, in Ōsaka and Edo (Fukaya nd.: 4.4).

When the restoration took place, Japan was still at the beginning of its socioeconomic modernisation process. The new administration gladly took over the modern factories, shipyards and mines that had been established by the bakufu and the different daimyō, and furthered economic development with large investments and the introduction of Western technology and Western engineers. Politicians like Ōkubo were convinced that the strength and weaknesses of a nation resulted from the poverty or prosperity of its people. That, however, to his mind was dependent on a nation's productivity. In his opinion, industrial productivity could only be enhanced through the development of knowledge and skill, something the Japanese people lagged behind with, in his view, and the government had to intervene (Tori- 
umi, Nihon no kindaishi, 31, quoted in Zöllner 2006: 225). Ōkubo perceived industrial fairs as being one method amongst others to spread practical knowledge and curiosity amongst the general public, thus becoming part of the educational programme supporting the politics to strengthen Japan (Hashizume 2005: 7).

When Kume Kunitake 久米邦武, the chronicler of the Iwakura mission, described the industrial fair in Vienna, he not only gave a vivid description of the location, but also noted that 'one might think the industrial achievements and craftsmanship of the European countries were founded in hundreds of years of learning. But actually, their history is not that long - this insight we owe to the World Exhibitions' (Kume 2002: 310), thus encouraging Japan to take part in the race. Also, by presenting an economy's goods in an international marketplace, he claimed national 'taste' could be refined and developed, while what nowadays would be called consumer studies and advertising could be conducted at the same time (Kume 2002: 313).

Sano Tsunetami, who had already visited the World Exhibition in Paris 1867 and was vice-director for Ōkuma Shigenobu during the Viennese one, had addressed a letter to the Council of State ten days before he travelled to Vienna:

If one held exhibitions to show natural products and manufactured ones as well as machines to a great number of people, the people's perception and knowledge would be enhanced. This way, exhibitions would be of use not only to science and education, but also for the industrial sector and trade. (Maruyama 2003: 61)

It seems Sano already had the idea of 'edu-tainment', because here, at the industrial fair, 'the visitors can, in an entertaining manner, develop an opinion regarding all the newly introduced innovations. Secondly, merchants and workers can enhance their products, adjusting them to the consumers' taste' (Hirayama Narinobu SakumuRoku 1925, quoted in Taitō-ku shisan senmon iinkai 2001: 69)

And again, the park played a crucial role in the discourse that took place around industrial fairs. Kume Kunitake and others pointed out that, apart from the existence of parks in all major European cities, they could be used for the military, for museums and for fairs, as for big fairs one needed a broad open space, and a functioning infrastructure surrounding the fairgrounds. Ueno Kōen was an obvious choice, and in 1876 Ōkubo Toshimichi proposed to the Dajōkan to hold an industrial fair in Ueno the following year (Taitō-ku shisenmon iinkai 2001: 69).

On 21 August 1877 the first National Industrial Fair, Naikoku Kangyō Hakurankai 内国勧業博覧会, opened on the grounds of Ueno Kōen, honoured and given special significance by the visit of the emperor. It was the first fair that had been held not by private groups, but by the Meiji-administration. It coincided with the Satsuma Rebellion that was to become so crucial in establishing a nationwide railway system. Troops had been stationed inside the park, and one can only imagine the gloomy atmosphere prevailing. A Tōkyō newspaper commented on that atmosphere on the occasion of the Second Industrial Fair held in Ueno, writing that 'at the 
time the industrial fair was opened for the first time, it took place amongst the war horses and soldiers, the mood was very peculiar.... This time, however, the atmosphere of the place is full of beauty' (Taitō-ku shisan senmon iinkai 2001: 71-72).

Furthermore, the fact of the fair having been held in times of political uproar and dissent gave out a highly political message, since

[...] the chief minister [Ōkubo Toshimichi] was chairman of the planning committee. He was a man of Satsuma, and the Satsuma Rebellion was just then in progress; and so the import of the exposition was highly political, to demonstrate that the new day had arrived and meant to stay, in spite of dissension. (Seidensticker 1983: 15)

The new army, built up by Yamagata Aritomo 山県有朋 and modelled after the Prussian army, proved to be superior to the samurai groups and was able to break the inner opposition and enforce the state's monopoly of violence (Schwentker 1999: 57).

In spite of the population's insecurities during those unstable times, the organisers tried to raise interest and enthusiasm for the fair, for instance by awarding prizes for exhibits. Takamura Kōun 高村光雲 (1852-1934), a sculpture of Buddhist images and later lecturer at the Tōkyō School of Fine Arts, won the best prize. However, he was mainly puzzled by the whole event. Firstly, he did not know what a hakurankai, this new institution, was supposed to be in the first place. Secondly, he thought the whole endeavour was mainly annoying anyway. When his showpiece won the best prize, he was invited to the awards show, where he appeared dressed in his traditional hakama 袴, completely oblivious to the bunmei, i.e. Western, connotation of the entire event. Moreover, after he had received the prize, he was completely unable to classify its significance (Taitō-ku shisan senmon iinkai 2001: 70-71).

Still, in spite of a severe lack of information and the surrounding circumstances, the fair managed to draw 454,168 visitors. Although the economic outcome was negative, it was decided to hold similar fairs every five years (Hashizume 2005: 18), and the overall review was positive (Seidensticker 1983: 115). An unintentional outcome of the fair was the implementation of the first 'shopping malls'. As the tradesmen did not manage to sell all their goods during the exhibition and wanted to avoid selling them at a lower price during its duration, they established so-called $k a n k \bar{o} b a$ 観工場, where the goods were sold at a set price, thus establishing 'onestop shopping' in Japan. In the beginning of the 20th century, these kankōba were replaced by department stores of the trading firms Mitsukoshi and Matsuzakaya (Hashizume 2005: 17).

The successive fairs in 1881 and 1890 managed to draw the attention of many more visitors and were held on a much larger scale. Spectacles for the visitors were set up, and all in all, the fair of 1881 presented itself as 'a second great showpiece for the fruits of civilised process' (Waley 1984: 159). Foreigners visiting the fair numbered 246, and apart from the Japanese products exhibited, Western products 
such as life-size display dummies and two electric trams that drove a short way through the fair grounds, surprised and probably amazed the visitors (Hashizume 2005: 24).

The next fair in Tōkyō took place in 1907, again on the grounds of Ueno Kōen, 'and it remains the grandest of the Tokyo series' (Seidensticker 1983: 115). Financed through public funds and donations from the citizenry, this time the city of Tōkyō was the host (Hashizume 2004: 44). With a water slide and a 21m-high ferris wheel, a water fountain and numerous blue, red and green lights, a lot of attention was paid to the visitor's entertainment, and possibilities for amusement were endless (Hashizume 2005: 47). With all the lights, the fair became a symbol of the bunmei kaika (Taitō-ku shisan senmon iinkai 2001: 74). Taking place at the time of the victory over Russia, the fair gained a patriotic importance that, according to Seidensticker, even had a therapeutic effect (Seidensticker 1983: 115). The fairs in Ueno became taste-makers for the Taishō period, and in spite of their always ending in the red, the city evaluated the fairs as successful and emphasised their importance for industry and trade (Taitō-ku shisan senmon iinkai 2001: 73-75).

\section{Ueno Kōen: a park with a view}

'When you go to Ueno you feel that the day's work is not yet finished', Saitō Ryoku'u wrote about Ueno Kōen. Silent and mute, but still a park with a view (Seidensticker 1983: 119). Taking into account that a space is constituted by the atmosphere staged in it, its spatial objects and the discourses surrounding them, this perception might be considered very accurate. Ueno was designed as a space of the bunmei kaika, the enlightenment of the people, and fukoku kyōhei, enrichment of the nation through a strong military. All its spatial objects were meant to interfere in reality and mediate between these slogans which shaped the Meiji era and the people living in Meiji Japan. Thus, they became dispositif, material objects of a very predominant discourse of the Meiji era. The park was not mainly (re)designed for the recreation of its visitors, but for their education. The park mirrors the aim of Meiji politicians to turn the Japanese people into the citizens required and desired by the modern nation state. Thus, the park can be viewed as a mirror of its time - of the Meiji era's aims, hopes and political ideas. It embodied these through its spatial structure and carried a view into a future anticipated by the powerfully acting people. Visiting Ueno Kōen, one might very well have felt that the day's work was not yet done - much more that the day's work had just begun.

The park became a space of 'Westernisation' or 'Europeanisation' through the neologism kōen and the regulations surrounding it, part of a reformed law system necessary for the modern state. Since the institution or, rather, idea, of the public park was used by some to transport even opposing political ideas, it became part of 
the space of political discussion. Ueno Kōen, moreover, became a space for education and socialisation through the museums, the library and the zoo placed in it.

With the help of Keller's theory of discourse analysis, which enables one to read even chronologically far apart incidents as discursive events in one discourse, it is possible to draw a line to the year 1920. In 1920, Japanese blue-collar workers for the first time in Japan celebrated Labour Day on the first of May, in the grounds of Ueno Kōen, with the slogan 'come to Ueno Kōen'. Up until 1936, Labour Day was celebrated regularly in Ueno Kōen (Maruyama 2003: 91). However, before Ueno was to become a space of the Japanese working class for one day a year, it became a space of the modern nation state, since Ueno was "never, however, a park for the enjoyment of nature but more a place for the cultural instruction and advancement of the citizenry' (Waley 1984: 159). Through its spatial objects, Ueno became a space of knowledge, symbolic order and modernity.

Ueno Kōen turned into a space of modernity by the objects placed in and around it. According to Giddens, there are four institutional dimensions of modernity:

1. Capitalism: Capital accumulation in the context of competitive labour and product markets

2. Industrialism: Transformation of nature: development of the 'created environment'

3. Surveillance: Control of information and social supervision

4. Military power: Control of the means of violence in the context of the industrialisation of war (Giddens 1990: 59)

The discourses surrounding Ueno Kōen, but also the spatial objects placed in Ueno, represent the dimensions of modernity. As Giddens writes:

The administrative system of the capitalist state and of modern states in general, has to be interpreted in terms of the coordinated control over delimited territorial arenas which it achieves. [...] Such administrative concentration depends in turn upon the development of surveillance capacities well beyond those characteristic of traditional civilisations, and the apparatuses of surveillance constitute a third institutional dimension associated, like capitalism and industrialism, with the rise of modernity. (Giddens 1990: 57-58)

The museums were apparatuses which directly supervised the activities of subject populations in the political sphere, especially through their importance for the school system. But they also indirectly controlled information. The industrial fairs were institutions which, very much like the museums, were meant to spur competitive labour and product markets. The railway, present at Ueno Kōen with Ueno station, the first connection between the capital Tōkyō and the north, only came into being because it proved its value to the military in 1877 , enabling the monopoly control of the means of violence for the modern nation state. 'The successful monopoly of the 
means of violence within territorially precise borders is distinctive to the modern state' (Giddens 1990: 58). By placing the statue of Saigō Takamori in the grounds of Ueno Park in 1898 (Seki 2005: 118), the opposition to the Meiji state was symbolically integrated into the space of legitimate power - at least in Ueno Kōen.

Ueno Kōen was, indeed, a park with a view. As a symbolic space, it showed Japan's transformation into a modern nation state and the implications of this development to its citizens. Ueno Kōen might have been the exact opposite of the park of the low city, Asakusa Kōen. Such a place might not have been very suitable for rowdy drinking, chattering and pure enjoyment, since it always reminded the visitor of what was left to do, what there was to strive for and what was expected of the modern citizen. 


\section{REFERENCES}

Bix, Herbert P. Hirohito and the Making of Modern Japan. New York: Harper Collins Publishers, 2000

Dirlmeier, Ulf, Andreas Gestrich, and Ulrich Herrman. Deutsche Geschichte. Stuttgart: Reclam Verlag, 1999

Ericson, Steve J. The Sound of the Whistle: Railroads and the State in Meiji Japan. Cambridge MA: Harvard University Press, 1996

Exposeeum e.V. "Die Weltausstellung 1873 in Wien.” Exposeeum Society Web site, 2000. http://www.expo2000.de/expo2000/geschichte/detail.php?wa_id=4\&lang=2\&s_typ=14, accessed June 2006

Fukaya, Katsumi 深谷克己. “Edojidai gohan no bunka” 江戸時代後半の文化 [Culture during the second half of the Edo period], nd. Waseda University Web site. http://www.f.waseda.jp/fky0/edo3.html, accessed June 2006

Giddens, Anthony. The Consequences of Modernity. Cambridge: Polity Press, 1990

Hall, John Whitney. Das Japanische Kaiserreich. Frankfurt a. Main: Fischer Taschenbuch Verlag, 1994

Hashizume, Shin’ya 橋爪紳也. Nihon no hakurankai. Terashita Tsuyoshi korrekushon 日本の博 覧会。寺下勍 コッレクション[Japanese industrial fairs. The Terashita Tsuyoshi collection]. Bessatsu taiyō, nihon no kokoro: 133. Tōkyō: Heibonsha, 2005

Howland, Douglas. R. Translating the West: Language and Political Reason in Nineteenth-century Japan. Honolulu HI: University of Hawaii Press, 2002

Huffman, James L. Creating a Public: People and Press in Meiji Japan. Honolulu HI: University of Hawaii Press, 1997

Iwata, Masami 岩田正美. Hōmuresu/gendai shakai/ fukushi kokka. “ikite iku bashō” wo megutte. ホームレス/現代社会/福祉国家.「生きていく場所」をめぐって [Homelessness/modern society/social welfare state. "About the place one lives at"]. Tōkyō: Meiseki Shoten, 2000

Keller, Reiner. Wissenssoziologische Diskursanalyse. Grundlegung eines Forschungsprogramms. Wiesbaden: VS Verlag für Sozialwissenschaften GWV Fachverlage GmbH, 2005

Kreckel, Reinhard. Politische Soziologie der sozialen Ungerechtigkeit. Frankfurt: Campus-Verlag, 1992

Kume, Kunitake Die Iwakura-Mission. Das Logbuch des Kume Kunitake über den Besuch der japanischen Sondergesandtschaft in Deutschland, Österreich und der Schweiz im Jahre 1873. Trans. and ed. Peter Pantzer, in cooperation with M. Eichorn, Kerstin Hilker, L. Narangoa and Monika Schrimpf. München: Iudicium, 2002

Lokowandt, Ernst. "Die rechtliche Entwicklung des Staats-Shinto in der ersten Hälfte der MeijiZeit (1868-1890).” Ph.D. dissertation, Rheinische Friedrich-Wilhelms-Universität zu Bonn, 1976

Löw, Martina. Raumsoziologie. Frankfurt a. Main: Suhrkamp, 2001

Löw, Martina. "The Constitution of Space. The Double Existence of Space as Structural Odering and Performative Act.” Lecture, March 14, 2005. Paris I/Sorbonne. http://raumsoz.ifs.tudarmstadt.de/pdf-dokumente/loew-constitution-of-space.pdf, accessed March 2009

Maruyama, Hiroshi 丸山宏. Kindai nihon kōenshi no kenkyu 近代日本公園史の研究 [Research on the history of parks in modern Japan]. Tōkyō: Shibunkaku Shuppan, 2003

Mason, R.H.P. and J. G. Caiger. A History of Japan. Boston: Tuttle Publishing, 1997

Pascha, Werner. Die japanische Wirtschaft. Mannheim, Leipzig: BI Taschenbuchverlag, 1994 
Prior, Lindsay. The Social Organization of Death: Medical Discourses and Social Practices in Belfast. New York: N.N. Quoted in Keller 2005:181

Seidensticker, Edward. Low City, High City. Tokyo from Edo to the Earthquake. New York: Alfred A. Knopf, 1983

Seki, Hideo 関秀夫. Hakubutsukan no tanjō. Machida Hisanari to tōkyō teishitsu hakubutsukan 博 物館の誕生一町田久成と東京帝室博物館 [The birth of the museum. Machida Hisanari and the Imperial Museum Tōkyō]. Tōkyō: Iwanami Shoten, 2005

Schwentker, Wolfgang. "Die 'lange Restauration'. Japans Übergang vom Shōgunat zur MeijiÄra.” In Ostasien. Geschichte und Gesellschaft im 19. und 20. Jahrhundert, ed. Sepp Linhart and Erich Pilz. Wien: Promedia, 1999

Shibusawa, Keizo, ed. Japanese Life and Culture in the Meiji Era. Tokyo: The Toyo Bunko, 1958

Shirahata, Yōzaburō 白幡 洋三郎. “An Encounter of European and Japanese Concepts in the Field of Urban Planning History, with the Urban Park as a Symbolic Example.” In International Symposium: The Transfer of Science and Technology between Europe and Asia, 1780-1880. The Second Conference on the Transfer of Science and Technology between Europe and Asia since Vasco da Gama (1498-1998). November 3-7, 1992, ed. Yamada Keiji. Kyoto and Osaka, Japan: International Research Center for Japanese Studies, 1992

Shirahata, Yōzaburō 白幡洋三郎. Kindaitoshi kōenshi no kenkyū. Ōka no keifu 近代都市公園史 の研究一欧化の系譜 [Research on the history of modern parks. A genealogy of Westernisation]. Tōkyō: Shibunkaku Shuppan, 1995

Suimatsu, Shirō 末松 四郎. Tōkyō no kōen tsūshi 東京の公園の通史 [History of Tōkyō's parks], vol. I. Tōkyō: Kōgakusha, 1981

Taitō-ku shisan senmon iinkai 台東区資産専門委員会. Taitōkushi. Tsūshihen 台東区史。通史 編 [History of the Taitō quarter], vol. III. Tōkyō: Taitō-ku, 2001

Totman, Conrad. A History of Japan. Malden MA: Blackwell Publishing, 2005

Waley, Paul. Tokyo Now and Then. New York: Weatherhill, 1984

Zöllner, Reinhard. Geschichte Japans. Von 1800 bis zur Gegenwart. Paderborn: Ferdinand Schöningh, 2006 


\section{GLOSSARY}

Ame Yoko

Asakayama Kōen

Asakusa Bunko

Asakusa Kōen

bakufu

Baku-han taisei

baku-han

bakumatsu

Batavia Shimbun

bunka no mori

bunka sōchi

bunko

bunmei kaika

bunmei sōchi

bussan-e

chiken

Chōya Shimbun

daimyō

Dajōkan

Edojidai gohan no bunka

en

fu

Fukagawa Kōen

Fukaya Katsumi
アメ横

浅香山公園

浅草文庫

公園

幕府

幕藩体制

幕藩

幕末

バタビア新聞

文化の森

文化装置

文庫

文明開化

文明装置

物産会

地券

朝野新聞

大名

\section{太政官}

江戸時代後半の文化

園

付

深川公園

深谷克己 shopping district in Tōkyō's Taitō-ku, i.e. in very close proximity to Ueno Park and Ueno station

Asakayama Park

Asakusa Library

Asakusa Park

'tent government', shogunal governments at Kamakura, Muromachi, Edo* 'power structure of bakufu and daimyō domains', refers to Edo bakufu and daimyō domains (han) as a single governing system*

elided form of 'bakufu-and-han', cf. baku-han taisei*

final years of the Edo period from 1853 onwards abbr. for kanban batabia shimbun, newspaper published by the Dutch occupation government in Indonesia and translated by the bakufu

'cultural forest', referring to Ueno Kōen as a place designated for high culture, i.e. museums and the like cultural artefact / institution Library 'civilisation and enlightenment', a policy ideal of Meiji reformers* artefact/institution of 'enlightenment' exhibition of plants and herbs land titles Choya Newspaper 'great name', regional magnates of medieval Japan; standardised during Edo period as officially enfeoffed holders of domains of 10,000 koku or greater putative yield* Great Council of State, senior official body of the ritsuryō system "Culture during the second half of the Edo period", article by Fukaya Katsumi Garden municipal prefectures of Tōkyō, Ōsaka and Kyōto Fukagawa Park Japanese historian 
fukoku kyōhei

Fukuzawa Yukichi

haibutsu kishaku

hakama

hakubutsukan

Hakubutsukan no tanjō.

Machida Hisanari to tōkyō

teishitsu hakubutsukan

hakurankai

hanatori chaya

handoki

Hashizume Shin'ya

Hibiya Kōen

Hibiya Yakuichi Jiken

honzō-e

Hosogawa Junjirō

'Ikite iku bashō' wo megutte

Inōe Kaoru

iroha karuta

Iwakura Tomomi

Iwata Masami

kakushō kansei

kankōba

kariya

ken
観工場

仮屋

富国強兵

副沢諭吉

廃仏毀釈

袴

博物館

博物館の誕生一町田

久成と東京帝室博物

館

博覧会

花鳥茶屋

半時

橋爪紳也

日比谷公園

日比谷焼打事件

本草会

細川潤次郎

「生きていく場所」

をめぐって

井上馨

いろはカルタ

岩倉具視

岩田正美

各省完成

県
'Rich country, strong army', policy ideal during the Meiji period, referring to the policies of 'enrichment of the nation through a strong military' (1835-1901) Japanese intellectual; visited San Francisco during the first official Japanese mission to America, later member of the meirokusha anti-Buddhist iconoclasm formal menswear skirt* Museum

"The birth of the museum. Machida Hisanari and the Imperial Museum”, written by Seki Hideo exposition, fair exhibitions of animals during the Edo period

traditional Japanese unit of time Japanese historian

Hibiya Park

Hibiya Incendiary Incident; massive antigovernment rioting by the common people of Tōkyō against the terms and conditions of the Treaty of Portsmouth exhibition of plants and herbs (1834-1923)

"About the place one lives at", written by Iwata Masami

(1835-1915) one of the leading figures of Meiji politics

Japanese playing cards

(1825-1883) one of the leading figures of Meiji politics, led Iwakura Mission 18711873, Japanese study group to Europe and America

Japanese sociologist definition of the administrative and legal rules and responsibilities for all ministries

first modern 'shopping malls', where different merchants sold their products independently from each other, but under one roof, 'one-stop shopping'

'temporary housing', homeless people's makeshift houses, tents

Prefecture 
Kindai nihon kōenshi no kenkyu

Kindaitoshi kōenshi no kenkyū. Ōka no keifu

kō/oyake

Kōchiken Heimin

Kōen

Kokuritsu Hakubutusukan

Kokuritsu Kagaku Hakubutsukan

Kokuritsu Seiyō Bijutsu Kan

Kume Kunitake

Kurimoto Jōun

Machida Hisanari

Maejima Hisoka

Maruyama Hiroshi

Matsudaira Sadanobu

Matsukata Masayoshi

Meirokusha

Naikoku Kangyō Hakurankai Nihon no hakurankai. Terashita Tsuyoshi korrekushon

Nihon Tetsudō Kaisha

Nōshōmushō

Ōkubo Toshimichi

Ōsaka Heimin Shimbun

Ritsuryō system

Saigō Takamori
近代日本公園史の研 究

近代都市公園史の研 究一欧化の系譜

公

高知県平民

公園

国立博物館

国立科学博物館

国立西洋美術館

久米邦武

栗本鋤雲

町田久成

前島密

丸山宏

松平定信

松方正義

明六社

内国勧業博覧会

日本の博覧会。寺下

勍コッレクション

日本鉄道会社

農商務省

大久保利通

大阪平民新聞

律令

西郷隆盛
"Research on the history of parks in modern Japan", written by Maruyama Hiroshi

"Research on the history of modern parks. A genealogy of Westernisation", written by Shirahata Yozaburō

Chinese character for public, official

Kōchiken Heimin newspaper

public park

National Museum

National Science Museum

National Museum of Western Art

(1839-1931) historian, chronicler of the Iwakura mission

(1822-1897) journalist

(1838-1897) first museum director in

Japan

(1835-1919) politician and businessman in Meiji period; founder of Japanese postal service

Japanese historian

(1758-1829) bureaucrat and charismatic politician

(1835-1924) finance minister; initiated a rigorous policy of retrenchment, 'Matsukata deflation'

'Meiji Six Society', group of Japan's leading intellectuals

National Industrial Fair

"Japanese industrial fairs. The Terashita

Tsuyoshi collection", written by Hashi-

zume Shin'ya

Japanese Railway Company, successor of the former Tōkyō Railway Association Ministry of Agriculture and Commerce (1830-1878) one of the leading figures of Meiji politics; assassinated 1878

Ósaka Heimin Newspaper system of penal and civil codes* (1827-1877) Satsuma samurai and one of the most prominent figures of the Meiji Restoration; left the government in protest over the Korea issue; led Satsuma rebellion, committed suicide in 1877 (1868-1904) Japanese poet and writer 
Sankinkōtai system

Sano Kanae

Sano Tsunetami

Sei-in

Seinan-sensō

Seki Hideo

Shiba Kōen

Shichōson system

shinmin

Shirahata Yōzaburō

Shisei tokurei no haishi

Shitamachi

Shōgitai

Shokusan kōgyō intiative

Shūko jisshu

Suimatsu Shirō

Sūmitsuin

Taitō-ku Shisan Senmon

Iinkai

Takamura Kōun

Tōkyō Nichinichi Shimbun

ukiyo-e prints

Tōkyō no kōen tsūshi

Ueno Kōen

Yamagata Aritomo

Yamao Yōzō

yūen
参勤交替/参勤交代

佐野鼎

佐野常民

正院

西南戦争

関秀夫

芝公園

市町村

臣民

白幡洋三郎

市制特例の廃止

下町

彰義隊

殖産興業

集古十種

末松四郎

枢密院

台東区資産専門委員 会

高村光雲

東京日々新聞

浮世絵

東京の公園の通史

上野公園

山県有朋

山尾庸三

遊園 system of alternating residence and attendance of the daimy $\bar{o}$, who were forced to spend time in Edo; their wives and children were forced to stay in Edo during the daimyō's visit to his home domain; system was abandoned 1862 (1831-1877) wrote the hōbeinikki 訪米日 記 [Diary on my visit to the West] (1822-1902) served, amongst other political posts, as minister of agriculture and commerce

together with $S a$-in 左院 and $U$-in 右院, the Sei-in formed the Dajōkan

'South-West War', Satsuma Rebellion 1877

Japanese historian

Shiba Park

the communal order (literally cities, towns and villages)

commoner

Japanese historian

the abandonment of the special municipal law 1898

'low city', the old part of Tōkyō

'troops of clear duty'

political initiative to promote Japanese

industry

"Ten categories of collected antiquities", written by Matsudaira Sadanobu

Japanese historian

Privy Council

Historical Society of the Taitō quarter

(1852-1934) Buddhist sculptor who produced huge images of national heroes Tōkyō Nichinichi Newspaper woodblock prints

"History of Tōkyō's Parks", written by Suimatsu Shirō

Ueno Park

(1838-1922), Meiji politician and military reformer

(1837-1917) samurai of the late Edo period and member of the Meiji government

pleasure grounds, garden 